\title{
Inclusive University Classrooms: the importance of faculty training
}

Morgado, Beatriz ${ }^{\mathrm{a}}$; Melero, Noelia ${ }^{\mathrm{b}}$; Molina, Victor ${ }^{\mathrm{c}}$ and Cortés-Vega, María Dolores ${ }^{\mathrm{d}}$

${ }^{a}$ Department of Developmental and Educational Psychology, University of Seville, Spain, ${ }^{\mathrm{b}}$ Department of Teaching and Education and Organization, University of Seville, Spain, ${ }^{\mathrm{c}}$ Department of Physical Chemistry, University of Seville, Spain, ${ }^{\mathrm{d}}$ Psysiotherapy, University of Seville, Spain.

\begin{abstract}
The presence of students with disabilities in the universities is increasing. Faculty needs to be trained in order to attend these students and with the objective to offer and inclusice education. The aim of this paper is to identify, describe and explain the barriers and aids that students with disabilities experience in university classroom. Forty four students with disabilities participated in the research. A biographical narrative methodology was used. The university-life histories of the students were complied by making use of in-depth interviews, lifelines and photographs. Results indicate the important of faculty training in matters concerning disabilities and new technologies, informing to the faculty of the presence of students with disabilities in their classroom, the existence of a specific service to support the faculty and the important of improving a positive attitude toward the disability. These results are dicussed in line with other studies. Recommendations are maded according to inclusive education and offering keys to universities to provide training plans leading to inclusive education and learning.
\end{abstract}

Keywords: students with disabilities; high education; faculty training; inclusive education. 


\section{Introduction}

In 1998, the UNESCO World Declaration on Higher Education, based on the Universal Declaration of Human Rights (WHO, 1948), forged a new vision of higher education, which underscores the right of every person to an education and equal rights of access to higher studies for all. Fuerthemore, the Convention on the Rights of Persons with Disabilities (UN, 2006) stated that persons with disabilities must be ensured access to higher education, professional training, adult education and life-long learning.

In Spain, Organic Law 4/2007 on universities had already referred to the inclusion of persons with disabilities at universities. It also included the obligation for university environments to be accessible, and inclusion of the principles of universal accessibility and respect for all in plans of study.

The number of university students with disabilities is increasing (Debram \& Salzberg, 2005). In this sense, universities should be inclusive and respond to the needs of the entire student body. Ferni and Henning (2006) explain that participation in educational environments is restricted by inaccessible curricula, negative attitudes of faculty and physical barriers. The social model of disability (Oliver, 1990) poses the need for restructuring these environments in such a way that the entire student body can participate and learn in them.

Many studies have been developed and highlighted that students with disabilities have to cope with continuing barriers, whether in the macro-institutional environment (inaccessible buildings and virtual environments, unending administrative bureaucracy, unapplied regulations, etc.) or in the micro-institutional classroom environment (negative attitudes and uniformed faculty members, strict, non-inclusive curricula, absence of adjustments, etc.) (Moriña, López, \& Molina, 2014). In this sense, students with an invisible disability, many often prefer not to reveal their disability because they are perceived negatively by others (Riddell \& Weedon, 2014). This is worrying because although in some cases, faculty members have helped the student and shown a positive attitude, many faculty has not been sufficiently sensitive or has shown a complete lack of training in how to attend these students in the classroom (Moswela \& Mukhopahdyay, 2011). This is important, and some of the key factors to success of students with disabilities include knowing the professors, and professors' attitudes or willingness to adapt curricula (Leyser, Greenberger, Sharoni, \& Vogel, 2011). Hadjikakou and Hartas (2008), mention that most faculty members have neither training nor previous experience in the subject of disability. In this sense, it is necessary to train and inform faculty members in matters referring to disability.

The main objective of this paper is to identity, describe and explain barriers and aids related to faculty that students with disabilities experience in classroom. 


\section{Method}

This study pertain to a wider research funded by the Spanish Ministry of Economy and Competiveness entitled, "University barriers and aids identified by students with disabilities." This four-year study (2011-2014) was carried out by a multi-disciplinary research team of professors from different areas and branches of knowledge (Education, Economics, Health and Experimental Sciences).

The research is based on a biographical-narrative methodology. Through it, it was attempted to make students with disabilities heard. It has been previously concluded that this type of methodology emphasizes the importance of people talking about themselves, without repressing their subjectivity. Therefore, as a methodology for research, it is most suitable for listening to the voices of groups such as students who could be suffering from discrimination. Specifically, the research was designed in two stages. After their informed consent had been acquired, 44 students participated in the first. Several different discussion groups were held (at least one in each of the five fields of knowledge ${ }^{1}$ ) and individual interviews (oral and written). In the second, in-depth life histories were constructed for 16 of the participants. Some of the instruments used for collecting data employed in these histories were the in-depth interview, photographs and lifeline. As the life histories were characterized by their polyphony, it was indispensable to include the voices of other persons in the university trajectories of the main characters.

This paper concentrates on the recommendations that university students with disabilities made for faculty training. Data were collected during three years. The range of age was between 19 to 59 years, being the mean 30.5 years old. Of these, 22 were men and 22 women. Twenty five percent of them were in the first year of their degree studies, $16 \%$ in the second, $25 \%$ in the third, $14 \%$ in the fourth and $9 \%$ in the fifth. The remaining, approximately $11 \%$, were studying for a master's degree. Finally, using the university's terminology, $38 \%$ of the students participating in the study had physical disabilities, $15 \%$ psychological disabilities, $36 \%$ sensorial disabilities and $11 \%$ had difficulties associated with some organic problem (asthma, degenerative diseases, etc.).

Data analysis was done from a double perspective. On one hand, for each history, what is called a narrative analysis as proposed by Goodley, Lawthom, Clough and Moore (2004) was done. On the other, a structural analysis (Riessman, 2008) was done for comparative analysis of all the information collected with all the techniques and people participating, using a system of categories and codes, as proposed by Miles and Huberman (1994) with the MaxQDA10 data analysis program.

\footnotetext{
1 The fields of knowledge included are: Health Sciences, Experimental Sciences, Social Sciences and Law, Engineering and Technology, and Humanities.
} 


\section{Results}

All participants identified faculty training in matters concerning disabilities as a necessary and unavoidable improvement, which the university must make. In fact, they recommended that the faculty be trained in the specific content referring to disability and the needs arising from it. In this respect, a basic demand that arose was that the faculty be informed of the different types of disability, since depending on which it is, the response may be different:

"RSP10": I think the most effective thing for training would be for them to have knowledge of the needs that each type of disability has, and how they can respond to it, like how to adapt notes to braille, Right?"

These students suggested too that it is necessary to make the faculty aware of the presence of students with disabilities in the classroom who must be given an appropriate, quality response. It is about making faculty members aware of the subject so they show a closer and more proactive attitude toward disability.

There should also be a service supporting the faculty in this matter, which could assist them whenever they found a student with a disability and did not know how to respond to him ${ }^{3}$.

"RCS4: But who supports the professor? ...it would be good if there were orientation specialists in higher education ...technical and educational adaptation, different clearer, concise teaching techniques ..."

Participants believed that professors received insufficient support from the university on how to respond to diversity. They commented, for example, on how faculty members often had to face students with disabilities in the classroom for the first time, but the information they received from the institution was minimal, and did not specify how to respond to the special needs of the students.

Several barriers related to the faculty were among the main obstacles identified by the participants in the study. Specifically, with regard to training, it was emphasized that the faculty is neither informed nor trained.

Other students emphasized that the problem was the absence of a positive attitude toward the disability. They suggested that it is complicated for the faculty to be trained to attend to

\footnotetext{
2 To protect the confidentiality of the participants in the study, abbreviations are used to identify them. Thus, RSC refers to Health Sciences, RSE to Social Sciences and Law, RSP to Social Sciences (Education), RTE to Engineering and Technology and Experimental Sciences and RH to Humanities. Each of these abbreviations is accompanied by a number that identifies the participant.

3 The only service which the University currently has for this purpose is the Disabled Student Services Office. Only one person with a degree in psychology works there, for a population which in academic year 2014/2015 was as many as 600 students. Therefore, the authors of this article believe that the question is not that the service does not exist, but that due to the large number of students it has to serve, the functions it performs are others.
} 
diversity because to do it, first they have to empathize with these students, and sometimes that is not the case.

The new technologies and how they can contribute to inclusion of students in the university was another of the points the students who participated in the study recommended to faculty.

In addition to insisting on making use of the new technologies in general, students with visual disabilities also made concrete proposals, like promoting the use of digital blackboards, or locating monitors on each desk so students could view the information the professor is projecting more easily. However, the barriers in this section appeared when faculty members decided not to use the technological tools they already had available to them, whether due to lack of interest or training in their use.

"RSP5: For a person who is blind, technology is always extremely important, because if it were not for today's technology... So of course, I think there is ignorance about the circumstances of each person with disability, but also about technology. Professors should be trained in this the same way they are trained in their field or subject."

The students also indicated that the university's virtual teaching platform was a huge help to them.

"RCS8: Virtual teaching platforms are very good and can be very useful to the student. However, this is another matter that should be reviewed, because there are professors who do not take this type of technological tool seriously."

\section{Conclusion and Discussion}

The students with disabilities who participated in this study recommended that faculty have to be infomed and trained in matters concerning disability. Therefore, faculty members must be made aware and have an opportunity for training to understand the advantages of inclusion. As Hurst (2006) says, training in disability should be obligatory for the entire staff. Such a training proposal should be based on the principles associated with effective learning for everyone and its sessions should be participatory. Thus it would be recommendable for universities to have a training plan so that its faculty can be adequately trained in dealing with these students.

Some universities have already accepted the challenge and have designed awareness training programs to prepare faculty members for this purpose (eg. Debran \& Salzberg, 2005; Guasch, 2010; Teachability, 2002). Some of these materials are more specific and concentrate on how to respond to the students depending on the type of disability, while others are broader, including matters referring to inclusive higher education (inclusive 
classroom methodology, curriculum adaptation, etc.). Zhang et al. (2010) recommend that to facilitate participation by faculty members, training should be online and go at their own pace.

Some content that seems to be indispensable in the design of faculty training for responding to the educational needs of students with disabilities, is the universal learning design (Watchorn, Larkin, Ang, \& Hitch, 2013). Applying a universal design to learning means guaranteeing equal access to teaching and learning, and as Pliner and Johnson (2004) suggest, conceiving of training from this perspective leads to benefiting not only students with disabilities, but also the rest of the students.

Finally, it is fundamental to consider the use of the new technologies inside and outside of the classroom to favor inclusion of students with disabilities (Pearson \& Koppi, 2006). As Seale (2006) explains, in many institutions, e-learning has become an essential tool of learning for many students. Several studies have already reported that the lack of faculty training could become a methodological obstacle and a significant educational barrier for students. Along this line, successful use of methods with specific tools for accessibility of students with disabilities, as some studies argue, not only depends on their technical nature, but also on teaching factors.

\section{References}

Debram, C. C., \& Salzberg, C. H. (2005). A validated curriculum to provide training to faculty regarding students with disabilities in Higher Education. Journal of Postsecondary Education and Disability, 18 (1), 49-62.

Ferni, T., \& Henning, M. (2006). From a disabling world to a new vision. En M. Adams and S. Brown (Eds.), Towards inclusive learning in higher education, pp.23-31. London: Routledge.

Goodley, D. Lawthom, R. Clough, P., \& Moore, M. (2004). Researching life stories. London: Routledge.

Guasch, D. (2010). Guía de actividades docentes para la formación en integración e igualdad de oportunidades por razón de discapacidad en las enseñanzas técnicas (Activity Guide for inclusive, equal opportunity training on disability management in Technical Studies). Barcelona: Cátedra de Accesibilidad de la UPC. Retrieved from:

http://upcommons.upc.edu/eprints/bitstream/2117/10245/1/Guia\%20Actividades\%20IO.pdf Hadjikakou, K., \& Hartas, D. (2008). Higher education provision for students with disabilities in Cyprus. Higher Education, 55, 103-119. doi: 10.1007/s10734-007-90708 . 
Hurst, A. (2006). Disability and maistreaming continuing profesional development in higher education. En M. Adams and S. Brown (Eds.), Towards inclusive learning in higher education, pp.56-66. London: Routledge.

Leyser, Y., Greenberger, L., Sharoni, V., \& Vogel, G. (2011). Students with disabilities in teacher education: Changes in faculty attitudes toward accommodations over ten years. International Journal of Special Education, 26 (1), 162-174.

Miles, M.B., \& Huberman, A.M. (1994). Qualitative data analysis. CA, USA: Sage Publications.

Moriña, A., López, R., \& Molina, V. (2014). Students with disabilities in higher education: a biographical-narrative approach to the role of lecturers. Higher Education Research \& Development. 34 (1), 147-159. doi: 10.1080/07294360.2014.934329

Moswela, E., \& Mukhopadhyay, S. (2011). Asking for too much? The voices of students with disabilities in Botswana. Disability \& Society, 26, 307-319. doi:10.1080/09687599.2011.560414.

Oliver, M. (1990). The politics of disablement. Basingstoke: Macmillan.

Pearson, E., \& Koppi, T.( 2006). Supporting staff in developing inclusive online learning. En M. Adams \& S. Brown (Eds.), Towards inclusive learning in higher education, pp.56-66. London: Routledge.

Pliner, S. M., \& Johnson, J. R. (2004). Historical, Theoretical, and Foundational Principles of Universal Instructional Design in Higher Education. Equity \& Excellence in Education, 37, 105-113. doi: 10.1080/10665680490453913.

Riddell, S., \& Weedon, E. (2014). Disabled students in higher education: Discourses of disability and the negotiation of identity. International Journal of Educational Research, 63, 38-46.

Riessman, C. K. (2008). Narrative methods for the human sciences. Los Ángeles: Sage Publications.

Seale, J. (2006). E-learning and disability in higher education: accessibility research and practice. Abingdon: Routledge.

Teachability (2002). Teachability project: Creating an accessible curriculum for students with disabilities. Glasgow: University of Strathclyde.

United Nations (UN) (2006). Convention on the Rights of Persons with Disabilities and Optional Protocol. Retrieved from http://www.un.org/disabilities/documents/convention/convoptprot-e.pdf

Watchorn, V., Larkin, H., Ang, S., \& Hitch, D. (2013). Strategies and effectiveness of teaching universal design in a cross-faculty setting. Teaching in Higher Education, 18, 477-490. doi: 10.1080/13562517.2012.752730. 
World Health Organization (WHO) (2001). International Classification of Functioning, Disability and Health. WHO: Geneva Switzerland. Recuperated from file:///C:/Users/anabel/Downloads/ICF_18.pdf

Zhang, D., Landmark, L., Reber, A., Hsu, H., Kwok, O., \& Benz, M. (2010). University Faculty Knowledge, Beliefs, and Practices in Providing Reasonable Accommodations to Students With Disabilities. Remedial and Special Education, 31 (4), 276-286. doi: 10.1177/0741932509338348. 